\title{
The Development of CDAC (Constructing, Design, Act, and Communicate) Learning Model in Education Research Course
}

\author{
https://doi.org/10.3991/ijet.v16i07.21221 \\ Nanda Harda Pratama Meiji, Joan Hesti Gita Purwasih, \\ Alan Sigit Fibrianto \\ Universitas Negeri Malang, Malang, Indonesia \\ Azmil Mohd Tayeb ( $\left({ }^{\prime}\right)$ \\ Universiti Sains Malaysia, Penang, Malaysia \\ azmil@usm.my
}

\begin{abstract}
This research developed a learning model containing life based learning approach in education research course of Sociology Education, Malang University. ADDIE development model was applied in this research development process. This learning model was developed following the procedural principle in the research, thereby called CDAC (Constructing, Design, Act, and Communicate) model. The procedure of CDAC learning model was as follows: 1) evaluation for constructing, 2) taking information for design, 3) collecting data for act, 4) innovation for communicate. In addition, this model is equipped with media including video and module developed to support the successful learning process. Having passed through evaluation and revision processes, the result of research showed that model and media developed is highly beneficial to the students and helped them provide the best research, as indicated with the satisfactory learning outcome achieved.
\end{abstract}

Keywords - Life-based learning, education research, learning model

\section{Introduction}

Life based learning approach is applied widely to vocational fields. The reinforcement of capability is the heart of this model. The principles in life based learning are: recognizing multiple source of learning, balancing integrity and utility, learners are responsible for their learning, organization are enablers, contradictions are strengths, developing the whole person, human dispositions are critical, change is qualitatively different, promoting a strength based orientation, and emphasizing on capability [1][2]. Although this approach is widely used in vocational studies, it does not mean that the principles contained therein cannot be developed for education in general. Many researches have shown that life based learning can improve student's skill by designing curriculum [3], learning models [4][5], and learning resources [6]. 
Based on life-based learning approach, the author develops a model in Educational Research courses to be applied to Sociological Education Study Program students. Educational research invites students to observe, to collect information, to process information, and to find recommendations to solve various education problems. This course is very important to prospective educators because they can develop new ideas, examine and justify their views through reference to a wider, and increase collective experience more widely [7]. Preparing the students to deal with the future challenge needs extra effort, particularly to educator students. In the future, they will not compete for themselves but should also educate the next generation and even contribute to society life [8][9]. Unfortunately, most students attending education generally have low achievement risk. It is because of some factors, among others: they have tendency of high-level research anxiety, poor learning habit, and too many educational researches taken before [10]. The constraints should be taken into account by the lecturers in the lecturing. In addition to improving the students' quality, such research also can improve the quality of lecturers as it reinforces adaptive teaching ability [11].

In contrast to the previous study, this learning model development emphasizes on three principles: 1) emphasizing on learning experience in real life, 2) developing syntax with contextual based design, and 3) utilizing technology and information effectively in the course. These three principles are included and designed in the learning set encompassing module, semester learning design, and course program unit. Additionally, to improve the students' understanding in the learning process, the authors develop learning material video media. In the future, these media can be utilized in the lectures.

\section{$2 \quad$ Method}

This research and development used Analysis, Design, Development, Implementation, and Evaluations (ADDIE) procedure [12]. This model is very compatible to be applied to develop student-oriented learning, thereby providing considerable meaningful learning [13]. The first was analysis stage. In this stag, the author analyzed the learning problem. Analysis was conducted through the lecturer's reflection on the learning experience passed through. Then, analysis was conducted by discussing with students. The second is design stage. In this stage, the author designed learning model. This stage was conducted by designing teaching-learning activities, from setting out the objective of learning, designing learning scenarios or teaching-learning activities, designing a learning set, designing learning material to evaluating the learning outcome. The third was developing stage. The design of learning model application was applied to the product ready to implement. The author put this stage onto semester learning design and lecturing program unit organized collaboratively between lecturers. The fourth was implementation stage. In this stage, the developer implemented the learning design and model developed. The developer held the activity in some meetings, in $9^{\text {th }}-17^{\text {th }}$ meetings. The model developed could not be completed in one face-to-face meeting. Therefore, it was conducted in several meetings. The fifth was evaluation stage. In evaluation stage, the developer analyzed the successful learning model applied. Evaluation was conducted both qualitatively and quantitatively. Qualitatively, it was carried out by 
means of discussion and peer reflection by the developing team. In addition, qualitative evaluation was conducted through interviewing students. Meanwhile, in quantitative evaluation, the lecturer carried out assessment through students' score gain and satisfaction.

\section{Result and Discussion}

\subsection{Analysis}

The results of learning reflection showed that there are several obstacles in Education Research course. There are three main factors underlying: Firstly, there are substantial materials in education research, secondly, it is limited, and thirdly the students' learning style tendency is relatively instantaneous. Therefore, to solve the problem, adequate field experience is needed. Meanwhile, the constraint of limited time in delivering material can be solved by preparing learning source corresponding to their leaning style, i.e. video. All of those aspects were then organized in a model development, thereby can improve the quality of learning.

\subsection{Design}

Instructional design applied included students' problem and need analyses, designing (setting out the objective goal to meet the students' need), implementation, and evaluation on product output [14]. The author planned the learning concept collaboratively. This method could improve collaboration between educators and learning effectiveness because of learning process transparency [15]. The author took the following measures in preparation stage: 1) Lecturer team held a discussion to design the learning innovation design together. 2) Lecturer team developed learning set consisting of semester learning design, learning source (module), media (learning video), and other instruments needed during the learning process. 3) Face-to-face lecturing was designed to teach more varying education types. Non-face-to-face lecturing was conducted in the form of field practice.

Having conducted preparation, the author entered into design of implementation stage with the following procedure: 1) Lecturing was conducted corresponding to the design developed by Lecturer through applying CDAC. 2) The main objective of lecturing activity is to invite the students to conduct educational research. 3) Project development is consulted with and monitored in each meeting. 4) The procedure results in research proposal and becomes the product all at once to score the mid-semester test. 5) Meanwhile, the report of research result becomes the product of final semester test scoring. The scoring was conducted through evaluation from student's and lecturer's points of view. Reflection activity was conducted by the team to improve the learning process. Evaluation on this successful model application can be seen from process and product produced by students. In addition, students were told to assess the extent to which this learning model benefits them. 


\subsection{Development}

The entire design stage is outlined in the CDAC model, and the draft is shown in Figure 1.

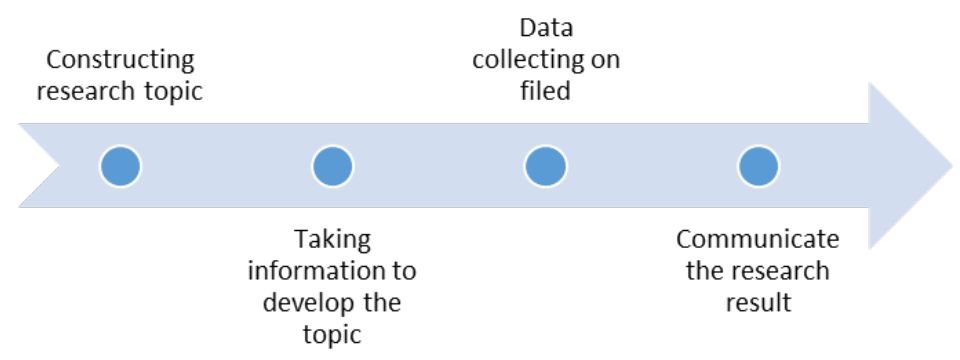

Fig. 1. Draft of CDAC learning model

This model in principle is adapted from the principle of research, including setting out topic, designing, collecting and analyzing data, and result. Research is a part of science body. As the part of science inheritance, learning is not a rite of presenting theories. Actual science is not given but a process of finding. It is this principle that becomes the foundation of CDAC model principle.

The draft of the CDAC model was refined through the first phase of trial. The first trial was conducted internally through construct evaluation by members of the developing team and the expert. The first trial for the model was carried out when reflecting the learning model design. The developers held a discussion to reflect together on the design prepared. Originally, the model developed focused on Construct, Design, Act, and Communicate only. The result of first trial for CDAC model is presented in the table 1.

Table 1. Result of first trial

\begin{tabular}{|c|l|l|}
\hline No. & Indicator & \multicolumn{1}{c|}{ Information } \\
\hline 1. & Objective & $\begin{array}{l}\text { The objective is not lecturer-oriented but the students should be given an oppor- } \\
\text { tunity of setting out their learning gain independently. Therefore, evaluation is in- } \\
\text { cluded into construct process. }\end{array}$ \\
\hline 2. & $\begin{array}{l}\text { Learning } \\
\text { Process }\end{array}$ & $\begin{array}{l}\text { Information exploration should be conducted on various media. Literacy culture } \\
\text { should be emphasized on. Nevertheless, more contextual life should be integrated } \\
\text { actually. Therefore, information stage is put before the preparation of a design. } \\
\text { Collaboration is needed between lectures and students. Process is an important gain, } \\
\text { in addition to final result. Therefore, periodical consultation is required. }\end{array}$ \\
\hline 3. & Usefulness & $\begin{array}{l}\text { The usefulness of learning outcome is felt not only by student. But actual learning } \\
\text { should also benefit many parties. Therefore, opportunity should be given to innova- } \\
\text { tion in disseminating learning outcome. }\end{array}$ \\
\hline
\end{tabular}

The trial was conducted not only on model design. The product of video and module was also tried internally and collaboratively. Revision was made on video media in the 
stage of designing material concept to be presented. Meanwhile, the module trial was conducted during designing the framework and content of book.

Revision on the product resulting from the first trial was used to make the product perfect. The model prepared was then perfected by adding predecessor activity giving typical characteristics to the CDAC model, as shown in figure 2.

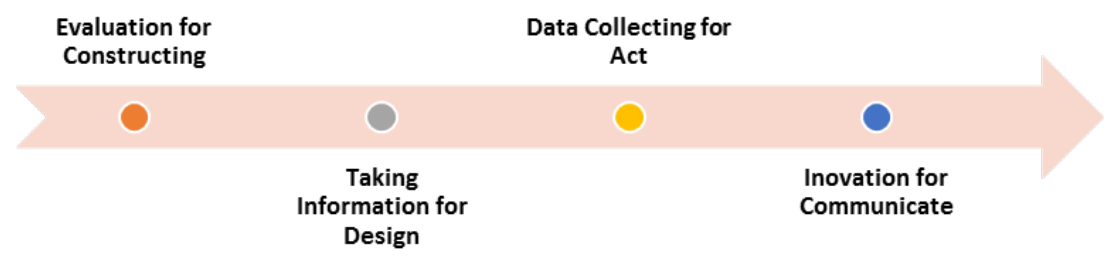

Fig. 2. Draft of CDAC learning model

Revision: 1) Evaluation for Constructing: adding evaluation process. 2) Taking Information for Design: adding information collecting process. 3) Data Collecting for Act: adding literacy enrichment and field process. 4) Innovation for Communicate: integrating media variety into beneficiaries

Video and module media revised internally by the members of developer were then revised again for its content and material, followed with product perfection and organization stage.

\subsection{Implementation and evaluation}

The implementation stage is shown by description of the CDAC learning model below:

Evaluation for constructing: Evaluation was conducted through reflection made by lecturers and students. This activity contains the reflection on previous learning experience, in which the students were told to express their grievances during the lecturing process. This attempt was taken to make the students and lecturers equally committed to improving the quality of learning. Furthermore, the lecturer describes the procedure of field research the students will conduct. Students and lecturers then construct an effective research design jointly.

Taking information for design: Lecturers elaborated the problems in education realm. It is intended to show the student a variety of research topics. The students were invited to search for information or other learning sources related to educational research. Meanwhile, in this development, the students got information prepared by the lecturers through video and module learning media. Video contains a variety of data collection techniques. Meanwhile, the module prepared contains a variety of educational research methods including qualitative, quantitative, mix and action research.

In addition to being obtained from module and video, information can also be obtained from experience and field study. The students were told to identify problems education realm actually. 
They were told to design or to construct their own knowledge independently through group activity. In this stage, the students can put design into research proposal. This process encourages them to think critically and to reflect their ideas. In this stage, the author also learns along with the students to identify new issues in educational research. In life based learning principle, the authors are also the learners attempting to develop the learning collaborative in their own workplace [16].

Data collecting for act: In this stage, the students conducted field research. Data collection was conducted corresponding to the design organized and consulted with the lecturer. The lecturers play very important role in this stage. Students were told to prepare consultation sheet to monitor the research and development process well.

Innovation for communicate: In this stage, the result of students' research was communicated to the public in some sources. The work and the result of research are varying according to the interest and topic developed by the group. As such, the products yielded are varying as well, including media, model, and research result. The outcome they obtain, at least can be communicated in the classroom learning. However, some other channels can also be used: journal and media for related education institution. In principle, the outcome of work produced is distributed to the public well in this stage.

The final evaluation of the CDAC learning model was conducted not only by the author, but also by considering the students' opinion during model implementation and media use. The result of reflection on model and media conducted collaboratively by developers and students is presented in the table 2 .

Table 2. Result of second trial

\begin{tabular}{|c|l|l|}
\hline No. & \multicolumn{1}{|c|}{ Indicator } & \multicolumn{1}{c|}{ Information } \\
\hline 1. & $\begin{array}{l}\text { Objective of } \\
\text { learning related to } \\
\text { the model }\end{array}$ & $\begin{array}{l}\text { It has been fairly clear and felt by both lecturers and students. Learning gives } \\
\text { the students' knowledge to find skill and competency they want to achieve. }\end{array}$ \\
\hline 2. & $\begin{array}{l}\text { Learning process } \\
\text { (model implemen- } \\
\text { tation process) }\end{array}$ & $\begin{array}{l}\text { Students agree that the learning process: is beneficial (80\%), is joyful (78\%), } \\
\text { gives actual learning experience in the field (95\%). }\end{array}$ \\
\hline 3. & Video Media & $\begin{array}{l}\text { Students agree that learning process: is clear and applicative (82\%) (neverthe- } \\
\text { less, there is a lack of sound effect). The video also understandable (85\%). }\end{array}$ \\
\hline 4. & Module Media & $\begin{array}{l}\text { Giving essential information and giving necessary information (1). With not } \\
\text { too many pages and having high readability (2). Giving adequate information } \\
\text { in the field (3). }\end{array}$ \\
\hline
\end{tabular}

Considering the result of reflection on model, the students perceive that the model have benefited them in the lecturing process. Nevertheless, the perfection of model, video, and module has been made to improve learning process and product (outcome). Overall, this research successfully benefits the students positively in understanding and applying educational research in the field. Generally, the result of evaluation on product assessment (result of research) shows satisfactory score, with mean score of 80 (A-) in the lecturing process.

Educational research is needed by students and lecturers to develop knowledge in the professional field [17]. Educational research is needed by students and lecturers to develop knowledge in the professional field. Therefore, in addition to adequate learning 
resources, it must also be organized in an adequate learning model. Therefore, in addition to adequate learning resources, it must also be organized with an adequate learning model. Integrating the real world into learning and research is a major challenge in the college curriculum [18]. Even so, this problem can be overcome by applying educational research starting from improving the internal quality of learning itself.

\section{Conclusion}

The result of development shows that the improvement of learning quality and process needs not only model but also media. Firstly, model design needs to be updated and developed as a teaching method. Secondly, the adequate participation of learning media is needed by students in acquiring information. These two elements are used and implemented together, thereby can provide innovation in the learning process.

In fact, the implementation of model containing life based learning should allocate more time out of class. Educational research course should give adequate space for the students to explore information and educational realm reality in the field actually. Therefore, this model is designed with 50\% face-to-face meeting in the classroom and $50 \%$ non-face-to-face meeting out of classroom. The use of technology media as lecturing source and process facilitates this model implementation.

The principle of lecturing benefiting widely should, of course, be promoted. Actual field lecturing should benefit not only unidirectionally, but it should do so multidirectionality for those beyond the campus/university.

\section{$5 \quad$ References}

[1] M. Staron, "Life-based learning model - a model for strength -based approaches to capability development and implications for personal development planning Maret Staron," Mindful Creat., 2011.

[2] M. Staron, M. Jasinski, and R. Weatherly, Life Based Learning In attendance, no. May. DARLINGHURST: TAFE NSW, 2006.

[3] H. Suwono, U. Lestari, B. Lukiati, and S. R. Lestari, "Building Undergraduates' Biological Capabilities through Reconstruction of Life-based Learning Curriculum," 2018. https://doi. org/10.2991/icli-17.2018.20

[4] Annita Kastur, Mustaji, and Yatim Riyanto, "Feasibility of Developing Direct Learning Models with a Life Based Learning Approach,” IJORER Int. J. Recent Educ. Res., vol. 1, no. 3, pp. 261-270, 2020. https://doi.org/10.46245/ijorer.v1i3.63

[5] A. A. Widianto, J. H. Gita Purwasih, and L. A. Perguna, "Promoting social cohesion: The development of elearning management system materials through life based learning for sociology of religion course,” Int. J. Emerg. Technol. Learn., vol. 15, no. 7, pp. 162-170, 2020. https://doi.org/10.3991/ijet.v15i07.13339

[6] N. Nurjanah, S. Soekopitojo, B. Wibowotomo, and T. M. Kiranawati, "Online Tengger Culinary Training Materials Using Life-Based Learning Approach for HORECA Industry," 2020. https://doi.org/10.1109/icovet50258.2020.9230125 
[7] C. Counsell, M. Evans, D. McIntyre, and J. Raffan, "The Usefulness of Educational Research for Trainee Teachers' Learning,” Oxford Rev. Educ., 2000. https://doi.org/10.1080/ 713688548

[8] Z. Arifin, "Menjadi Guru Profesional (Isu dan Tantangan Masa Depan)," EDUTECH, 2014. https://doi.org/10.17509/edutech.v13i1.3225

[9] H. Darmadi, "Tugas, Peran, Kompetensi, dan Tanggung Jawab Menjadi Guru Profesional," J. Edukasi, 2015. http://dx.doi.org/10.31571/edukasi.v13i2.113.

[10] A. J. Onwuegbuzie, J. R. Slate, F. R. A. Paterson, M. H. Watson, and R. A. Schwartz, "Factors Associated with Achievement in Educational Research Courses.," Res. Sch., vol. 7, no. 1, pp. 53-65, 2000.

[11] L. Lin, "An Evaluation System and Its Model for Educational Competitiveness of Universities Influencing Factors of Educational Competitiveness of Universities," pp. 188-201.

[12] R. M. Branch, Instructional design: The ADDIE approach. USA: Springer, 2010.

[13] C. Peterson, "Bringing ADDIE to life: Instructional design at its best," J. Educ. Multimed. Hypermedia, vol. 12, no. 3, pp. 227-241, 2003.

[14] N. Aldoobie, “ADDIE Model,” Am. Int. J. Contemp. Res., vol. 5, no. 6, pp. 68-72, 2015, [Online]. Available: https://www.instructionaldesign.org/models/addie/

[15] N. Zahiroh, S. Susanti, R. M. Iffani Amalia, and J. H. Gita Purwasih, "Tantangan Mengajar Pelajaran Fiqih Materi Khitan Pada Jenjang Sekolah Dasar," J. Pendidik. Agama Islam, 2018. https://doi.org/10.14421/jpai.2018.152-10

[16] N. Solomon, D. Boud, M. Leontios, and M. Staron, "Researchers are learners too: Collaboration in research on workplace learning," J. Work. Learn., 2001. https://doi.org/10.1108/ 13665620110411058

[17] E. Ingleby, "Research methods in education," Prof. Dev. Educ., 2012, doi: $10.1080 / 19415257.2011 .643130$.

[18] P. F. Oliva and W. R. Gordon, Developing the Curriculum, 8th ed. Upper Saddle River, NJ: Pearson, 2013.

\section{Authors}

Nanda Harda Pratama Meiji, Joan Hesti Gita Purwasih, Alan Sigit Fibrianto are from Universitas Negeri Malang, Malang, Indonesia.

Azmil Mohd Tayeb is from Universiti Sains Malaysia. azmil@usm.my

Article submitted 2021-01-10. Resubmitted 2021-02-17. Final acceptance 2021-02-18. Final version published as submitted by the authors. 


iJET - Vol. 16, No. 07, 2021

\section{Imprint}

iJET - International Journal of Emerging Technologies in Learning http://www.i-jet.org

\section{Editor-in-Chief}

Dominik May, University of Georgia, United States

\section{Executive Editor}

Michael E. Auer, CTI Frankfurt/Main, Vienna, New York, Bengaluru

\section{Associate Editors-in-Chief}

Martin Ebner, TU Graz, Austria

Mohammad Khalil, University of Bergen, Norway

\section{Associate Editors}

Neelakshi Chandrasena Premawardhena, University of Kelaniya, Sri Lanka

Christina Merl, Vienna, Austria

Jalal Nouri, Stockholm University, Sweden

Stamatis Papadakis, University of Crete, Greece

Valerie Varney, RWTH Aachen University, Germany

\section{Technical Editor}

Sebastian Schreiter, Lagorce, France

\section{Editorial Board}

A. Y. Al-Zoubi, Princess Sumaya University for Technology Amman, Jordan Gerald Friedland, International Computer Science Institute, Berkeley (CA), USA

Andreas Holzinger, Medical University Graz, Austria

Dr. George S. Ioannidis, University of Patras, Greece

Andreja Istenic Starcic, Slovenia University of North Texas, US

Barbara Kerr, Concordia University Montreal, Canada

Lars Knipping, TU Berlin, Germany

Massimo Marchiori, World Wide Web Consortium (W3C) at MIT

Andreas Pester, Carinthia University of Applied Sciences, Austria

Rob Reilly, University of Memphis and MIT Media Lab, USA

Cornel Samoila, Transilvania University Brasov, Romania

Mario Žagar, University of Zagreb, Croatia

\section{Indexing}

International Journal of Emerging Technologies in Learning is indexed in Clarivate Analytics ESCl, Elsevier Scopus, El Compendex, DBLP, Ulrich, EBSCO, INSPEC, LearnTechLib, and Google Scholar.

\section{Publication Frequency}

Bi-Monthly

\section{ISSN}

1863-0383

\section{Publisher}

International Association of Online Engineering (IAOE)

Kirchengasse 10/200

A-1070 Vienna

Austria 